\title{
Sovyetler Birliği’nde Din Karşıtı Propaganda: 1917-1960 Dönemi Üzerine Bir Değerlendirme
}

\section{- İsmailcan DOĞAN}

\author{
Dr. Öğr. Üyesi Erciyes \\ Üniversitesi \\ ismailcandogan@erciyes.edu.tr
}

ORCID ID: 000-0001-9855-5159

\begin{abstract}
ÖZET
1917 yılında Rusya'da Bolşeviklerin iktidarı ele geçirmesiyle yeni bir dönem başladı. Ekim Devrimi olarak adlandırllan bu dönemden sonra kurulan Sovyetler Birliği, döneminin en etkili güçlerinden biriydi. Lenin öncülüğünde kurulan devlet sosyalist dünya görüşüyle yönetilmekteydi. Dolayıslyla tüm dinlere karşı olumsuz bir bakış açısına sahipti. Bu nedenle devrimin ilk günlerinden itibaren tüm dinlere karşı agresif bir propaganda kampanyası başlatıldı. Ateist bir toplum inşa etmek için yillarca birçok propaganda yöntem ve tekniği kullanıldı. Ancak 1917-1960 yılları arası dönem Sovyetler Birliği’nde din karşıtı propaganda faaliyetlerinin en etkin yapıldı ̆̆ dönem olarak ele alınabilir.

Bu çalışmada Sovyetler Birliği’nde 1917-1960 yllları arasında yapılmış olan din karşıtı propaganda çalışmalarına odaklanılmıştır. Sovyetler Birliği'nin dinlere yönelik yaptiğ ateist propagandanın ve devletin bu doğrultudaki politikasının ele alındiğı çalışmamızda literatür taraması yöntemi kullanılmıştır. Çalışmanın amacı Sovyetler Birliği'nde devlet eliyle yürütülmüşs olan propaganda faaliyetlerini, din karşıtı propaganda özelinde incelemektir. Ayrıca yapılan din karşıtı propagandada hangi araçlardan faydalanıldı̆̆ yaymak için ne tür yöntemler kullanıldiğını ortaya koymak amaçlanmıştır. Sonuç olarak Sovyetler Birliği'nde 1917 yllından İkinci Dünya Savaşı'na kadar agresif bir din karşıtı propaganda yapıldiğı, savaş dönemi ve sonrasında ise bu tutumun terk edildiği görülmüş̧ür. Din karşıtı propagandada ise medya, eğitim ve yüz yüze propaganda araçları etkin bir biçimde kullanılmıştır.
\end{abstract}

Anahtar Kelimeler: Propaganda, Din, Din Karşıtı Propaganda, Ateizm, Sovyetler Birliği 


\section{Anti Religious Propaganda in the Soviet Union: A Assessment on the Period 1917-1960}

\section{- İsmailcan DOĞAN}

Asst. Prof. Erciyes Üniversitesi ismailcandogan@erciyes.edu.tr

ORCID ID: 000-0001-9855-5159

\begin{abstract}
A new era began in Russia in 1917 when the Bolsheviks seized power. The Soviet Union, established after this period, called the October Revolution, was one of the most influential forces of its era. The state, founded under the leadership of Lenin, was governed by a socialist worldview. He therefore had a negative view of all religions. For this reason, an aggressive propaganda campaign against all religions was launched from the early days of the revolution. Many propaganda methods and techniques were used over the years to build an atheist society. However, the period between 1917-1960 can be considered as the most effective period of anti-religious propaganda activities in the Soviet Union.

This study focused on anti-religious propaganda studies conducted in the Soviet Union between 1917 and 1960. In our study, which examined the atheist propaganda of the Soviet Union towards religions and the policy of the state in this direction, the literature review method was used. The aim of the study is to examine the propaganda activities carried out by the state in the Soviet Union in the anti-religious propaganda special. In addition, it is aimed to reveal what tools are used in anti-religious propaganda and what methods are used to spread atheism. As a result, aggressive antireligious propaganda was carried out in the Soviet Union from 1917 until the Second World War, and this attitude was abandoned during and after the war. In anti-religious propaganda, media, education and face-to-face propaganda tools were effectively used.
\end{abstract}

Keywords: Propaganda, Religion, Anti-Religious Propaganda, Atheism, Soviet Union 


\section{GİRIŞ}

20. yüzyıl ideolojik ve toplumsal olarak birçok insanı etkilemiş önemli olayların yaşandığı bir dönem olmuştur. Gerek dünya savaşları gerekse de devrimler gibi toplumsal hareketler bu dönemde kendisine yer bulmuş, bu olayların öncesinde ve neticesinde ortaya çıkan ideolojik akımlar ile birlikte toplumların yaşamları dizayn edilmiştir. Bu ideolojilerden birisi de hiç şüphesiz sosyalizmdir. Tarihte kurulmuş olan en önemli sosyalist devletlerden birisi bilindiği gibi Sovyet Sosyalist Cumhuriyetler Birliği (SSCB), bir diğer adıyla Sovyetler Birliği'dir. Sovyetler Birliği 1917 yılında Ekim Devrimi olarak adlandırılan ve Rus Çarının devrilmesinin ardından Bolşeviklerin kurduğu bir devlettir.

Devrimden sonra Sovyetler Birliği yeni rejimin kabul görmesi için her alanda propaganda çalışmaları yapmaya başladı. Devrimin ilk günlerinden itibaren Çarlık Rusya'sını devrimci bilinçle yeniden yapılandırmak amacıyla propaganda kampanyaları başlatıldı. Bunun için film, müzik, edebiyat, basılı medya, görsel sanatlar gibi bütün araçlardan faydalanıldı (Widdis, 2003, s. 3). Bilindiği gibi sosyalist dünya görüşü temel olarak tüm dinlere karşı olan bir görüştür. Bu nedenle filozoflar Karl Marx'la beraber Engels'in görüşlerinin 1şı̆̆ında Rus sosyalist ve Sovyetler Birliği’nin kurucusu olan Vladimir Lenin Ekim Devrimi'nden sonra Sovyetler Birliği'nde dinlere karşı politikalar geliştirmeye başlamıştır. Bu politikalar bizzat devlet eliyle yürütülmüş, aynı zamanda devletin de bir politikası haline gelmiştir. Sadece Lenin değil, kendisinden sonra Komünist Partinin başına geçen liderler de dinlere karşı benzer politikaları uygulamaya devam etmişlerdir. Bu kapsamda din karşıtı propagandayı da harekete geçiren Bolşevikler, sistemli olarak ülke genelinde sosyalist dünya görüşü olan ateizmi ve ateist propagandayı yapabildikleri her alanda yapmışlardır. Bu kapsamda yapılan din karşıtı propaganda çalışmaları medya vasıtasıyla, eğitim-öğretim alanında ve yüz yüze olmak üzere üç ana başlıkta ele almak mümkündür. Buradan hareketle çalışmamızda Sovyetler Birliği'nin temellerinin atıldığı 1917 yılı ile 1960 yılı arasında dinlere karşı yapılan propaganda çalışmalarının kapsamına ve mahiyetine yönelik bir değerlendirme yapılmıştır. Araştırmamızda yöntem olarak literatür taraması kullanılmıştır. Literatür taraması, herhangi bir konu hakkındaki yayınlanmış ya da yayınlanmamış olan bilgilerin, belgelerin, fikirlerin veya kanıtların seçilerek toplanması ve bunların dikkatli bir biçimde değerlendirilmesi olarak tanımlanabilir (Hart, 1998, s. 14). Çalışmamızda ise konunun literatürdeki durumu derinlemesine bir şekilde incelenmiştir. 
Çalışmamızda, söz konusu dönemde din karşıtı propagandayı anlamak için öncelikle propaganda ve dini/din karşıtı propaganda kavramları açıklanmış, daha sonra ise literatürdeki veriler 1şı̆̆ında Sovyetler Birliği’nin 1917-1960 yılları arasında dine bakışı ve politikaları propaganda bağlamında değerlendirilmiştir.

\section{PROPAGANDA VE DINİ/DIN KARŞITI PROPAGANDA}

Propaganda kavramının ne olduğu ile ilgili literatüre farklı yazarlar ve bilim adamları farklı tanımlamalar getirmiştir. Propaganda kavramını anlayabilmek için ilgili literatürde öne çıkan tanımlamalara bakmakta fayda vardır.

Çağımızı propaganda çağı olarak adlandıran Lasswell ve Blumenstock’un (1939: 1021) tanımına göre propaganda, tutumları kontrol altına almak için sembollerin manipüle edilmesidir. Onlara göre propaganda hedefine ulaşmak için karşısına çıkan tutumları zayıflatmaya ve yanında olanları ise desteklemeye yöneliktir. Bu tanımlamaya araç kavramını da ekleyen Qualter'a (1980: 279) göre propaganda, bir birey veya grup tarafından, başka bir bireyin veya grubun tutumlarını şekillendirmek, kontrol etmek veya farklılaştırmak için yapılan, bunu yaparken de farklı araçlardan yararlanılan bilinçli bir faaliyettir. Halkla ilişkiler mesleğinin kurucusu olarak bilinen Edward Bernays ise propagandayı halkın bir işletmeye ya da gruba yönelik olarak fikirlerini şekillendirmek ve tutumlarını etkilemek için yapılan tutarlı ve kalıcı bir çaba olarak tanımlamıştır (Bernays, 1928, s. 25).

Propagandanın tarihine bakıldığında ise Katolikliğin erken dönemlerine kadar uzandığ 1 bilinmektedir. Propaganda kelimesinin ilk defa "The Congregatio de Propaganda Fide" yani “İtikadı Yayma Cemaati” isimli Katolikliği Avrupa’da ve kolonilerde yaymak amaçlı grubun isminde yer aldığı görülmektedir. Ancak bilim adamları propagandada daha çok 20. yüzyıla odaklanmaktadırlar. Özellikle diktatörlük rejimlerinin doğuşu, gelişimi ve faaliyetleri sırasında yapılan propaganda çalışmaları bilim adamlarının daha fazla dikkatlerini çekmektedir. Hiç şüphesiz 19. yüzyılın sonu ile 20. yüzyılın başlarında kitle iletişim alanında yaşanan gelişmeler de o dönemdeki propaganda çalışmalarının sayısının artmasına neden olmuştur. Söz konusu alanda yaşanan gelişmeler ve gazete, radyo, televizyon gibi araçların icat edilmesi ve yaygınlaşmaya başlaması propaganda yaparlar için bulunmaz bir firsat olmuştur. Bu araçlar 
sayesinde ideolojilerini daha fazla kişiye yayma imkânı bulan propagandacılar (Lenone, 2017, s. 159) bunun yanında farklı yöntem ve teknikleri de kullanmışlardır.

Bununla beraber propaganda birçok farklı alanda yapılabilmektedir. Kaynağına göre, konusuna göre, sahasına ya da kapsamına göre farklı türlere ayrılan propagandanın yapıldığı alanlardan birisi de dindir. Dini propaganda, herhangi bir dini ya da mezhebi yaymak için yapılabileceği gibi, herhangi bir dine ya da mezhebe karşı da yapılabilmektedir. Örneğin misyonerlik faaliyetleri bir çeşit dini propagandadır. Din adamları çeşitli yerlere gönderilerek inanç propagandası yapmakta ve dine yeni insanlar kazandırmaya çalışmaktadır (Kı1ıç, 2006, s. 329). Öte yandan din karşıtı propaganda çalışmaları tek bir dine karşı yapılabileceği gibi bütün dinlere karşı yapıldığının örnekleri de tarihte mevcuttur. Sovyetler Birliği'ndeki din karşıı propaganda bunun belki de en örgütlü olanı olarak ele alınabilir. Zira Sovyetler Birliği devletinin bir politika haline getirdiği din karşıtı propaganda, devletin kurulmasından yıkılmasına kadar az veya çok etkisini göstermiştir. Sovyetler Birliği’nde din karşıtı propagandayı anlayabilmek için Sovyetler Birliği’nin kurulduğu Ekim Devrimi’nden öncesine ve Sovyetler Birliği’nin dine bakışına değinmekte fayda vardır.

\section{DEVRIM ÖNCESİ DÖNEM VE SOVYETLER BİRLİĞI’NIN DINNE BAKIȘI}

Sovyetler Birliği’nde dine olan bakışı anlayabilmek için 1917 sonbaharında yaşanan devrimin öncesindeki koşullar hakkında bilgi sahibi olmak gerekir. Devrimden önce Rusya'nın resmi dini Hristiyanlığın bir mezhebi olan Ortodoksluktu. Çarlık Tiranlığı, Ortodoks Kilisesi ile yakın temas halinde ilişkilerini sürdürmekteydi. Zira Kilise, Çarlık rejiminin meşruluğunu kitleler üzerinde yayarken, Çarlık rejimi de Kilisenin faaliyetlerine izin veriyor ve Kilisenin önde gelenleri bu durumdan faydalanıyordu. Bir başka ifadeyle iki taraf da karşılıklı çıkar ilişkisi içerisindeydi. Zaten Rus Çarının kendisi bizzat Kilisenin başında yer alıyordu. Bu çıkar ilişkisinden diğer dinler ve mezhepler de payını aldı. Yani diğer dinlere ve mezheplere getirilen kısıtlamalar Rusya'da Bolşeviklerin başa gelmesinden önce de mevcuttu. Özellikle Yahudilere karşı yapılan uygulamalar ve propaganda faaliyetleri bunu kanıtlar niteliktedir. Örneğin 1905 sonbaharında yüzden fazla olay meydana gelmiş ve bu olaylar neticesinde 3,500 insan hayatını kaybetmiş, 10.000 kişi ise yaralanmıştır. Üstelik bu olaylar Ortodoks Kilisesinin açık onayı ile 
gerçekleşmişti. Dahası Kilise, Çarlık rejiminin gizli servisi ile iş birliği içerisindeydi. Cemaatlerde rejime karşı olanları, devrimcileri ve liberalleri gizli servise bildiriliyordu. $\mathrm{Bu}$ nedenle o dönemlerde Rusya'da binlerce işçi, aydın ya da liberal görüşteki insanlar tutuklandı, öldürüldü ya da sürüldü. Bununla birlikte Kilise ile Çarlık rejiminin arasında ekonomik nedenlerden dolayı da bir çıkar ilişkisi bulunmaktaydı. Zira Ortodoks Kilisesi 1917 yılında yaşanan devrime kadar Rusya'daki en zengin kurumdu. Binlerce köylüyü sömüren Kilise, büyük bir zenginliğe sahipti. Devrim sırasında Kilisenin banka hesaplarında yaklaşık sekiz milyar ruble bulunmaktaydı. Ayrıca Kilisenin yıllık geliri yaklaşık yarım milyar rubleye dayanmaktaydı. Bunun dışında 20 milyon dönüm arazisi olan Kilisenin ayrıca yapılarındaki altın ve gümüş süslemelerinin muazzam değeri vard1. Bu zenginliğin sürdürülmesi de doğal olarak Çarlık rejiminin devamlılığına bağlıydı (Lamont, 1936, s. 3-5). Şüphesiz bu durumun Sovyetler Birliği döneminde yapılan din karşıtı propaganda için ateistlere bir zemin hazırladığını söylemek yanlış olmaz. Zira ateist propaganda sadece Kiliseye karşı değil, bütün inançlara karşı yapılmaktaydı. Devrimden önce de Çarlık ve Ortodoks Kilisesinin birlikte uyguladığı yukarıdaki politikalar neticesinde şüphesiz insanların Kiliseye, dolayısıyla dine bakış açılarında bir sarsılma olduğu düşünülebilir. Bu durumun da devrimden sonra yapılmaya başlanan din karşıtı propagandanın işini kolaylaştırdığını, Kiliseye karşı bir önyargı oluştuğunu söylemek yanlış olmaz.

Öte yandan 1890'larda Marksizm Rusya'da en fazla etkili devrimci öğreti olarak öne çıkmaktaydı. Marksizm öğretisinde dine karşı bir antipati mevcuttur. Bu bağlamda Rus devrimci ve aynı zamanda Sovyetler Birliği’nin kurucusu olan Lenin'in de dine karşı kişisel bir antipatisi vardı (Walters, 1986, s. 136). Diğer taraftan, bilindiği gibi sosyal demokrasi dünya görüşünü, bilimsel sosyalizm yani Marksizm temeline dayanmaktadır. Marksizm'in ise felsefi olarak temeli, 18. yüzyıl Fransa materyalizmi ve Almanya'daki Feurebach materyalizminin tarihsel geleneklerini benimsemiş olan materyalist felsefeye dayanmaktadır. Söz konusu bu maddecilik akımları ise tamamen ateist ve dinlere karşı olan diyalektik maddeciliktir. Bununla beraber din konusunda Karl Marx, Engels'i din felsefesine açık kapı bırakmakla suçlamakta, Engels ise Ludwig Feurbach ile ilgili yapıtında dini ortadan kaldırmak için değil de yeni bir din kurmak için savaş açtı diye Feuerbach'ı suçlamaktadır. Bütün bu tartışmaların 1şı̆̆ında Marksizm, "din kitleleri uyutan bir afyondur” görüşü temelinde bütün dinlere karşı tutum sergileyen bir dünya görüşüdür. Marksizm herhangi bir dini örgütlenmeye veya modern dinlere 
karşıdır. Zira bunları işçilerin ezilmesine ve sömürülmesine neden olan araçlar olarak görmektedir (Lenin, 1975, s. 25-26). Bununla beraber Sovyetler Birliği’ne geri dönersek, 191821 yılları arasında yaşanan iç savaştan bu yana Sovyetler Birliği'nde tek izin verilen parti Komünist Partidir. Toplumda örgütlenme hakkı da elinde bulunan Komünist Parti, devletin bütün organlarında oluşturulan ve oluşturulacak olan politikaların belirleyicisi konumundaydı. Sosyal ve kültürel bütün politikalarda rol oynayanlar ise parti içerisindeki aydınlardı ve bu aydınların hemen hepsi ateistti. Bu kişilerin dine ve özellikle de Rus Ortodoks Kilisesine olan düşmanlıkları da bilinen bir gerçekti (Walters, 1986, s.136). Sovyetler Birliği devletinde ateist propaganda ve dinlere yönelik saldırıların arka planında yukarıda bahsedilen, Karl Marx, Friedrich Engels ve Vladimir Lenin tarafından geliştirilen bilimsel materyalizm öğretisi ve onları takip eden Komünist Parti içerisindeki aydınlar bulunmaktadır. Ayrıca 1924 yılında Lenin'in ölmesiyle beraber, Bolşeviklerin içeresindeki ateistlerin kendilerini bu öğreti ve felsefenin mirasçısı olarak görmeleri Sovyetler Birliği'nde din karşıtlı̆̆ının oluşmasına zemin hazırlayan en önemli etkenlerden birisidir. Ateistler, Karl Marx, Friedrich Engels ve Vladimir Lenin'in öğretilerini Marksizm-Leninizm olarak bilinen bir eylem rehberi olarak gördüler. Fakat Marksizm-Leninizm'in yetersiz kaldığında, ateistler Sovyetler Birliği gerçekleri 1şı̆̆ında bu öğretiyi tekrar yorumladılar. Sonuçta söz konusu ideolojinin kurucularının da ötesine geçen bir bakış açısı oluştu (Roessler, 1990, s. 4).

Peki komünistler neden dini zararlı bir yapı olarak görmektedirler? Komünistlerin çoğu insanların dua ile Tanrı'dan sorunlarının çözümü için yardım istediklerini ve bu durumun insanların kendi somut düşünce ve eylemlerini ortaya koymaktan alıkoyduğunu savunmaktaydı. Dinin bilimin önündeki bir engel olduğunu düşünen komünistler, örneğin hasta çocuğu için ağlayan bir annenin ya da mahsul alamayan bir çiftçinin bilimsel bir prosedür başlatmak yerine dua ettiğini bunun da bilime ters düştüğünü savunmaktaydılar. Ayrıca dinin ölümden sonraki yaşam vaadinin işçilerin bu dünyadaki sömürülmesi karşısında mücadele etmesini engellediğini savunmaktaydılar (Lamont, 1936, s. 13-14). Şüphesiz Lenin'in din ile ilgili görüşleri de ateist propagandanın oluşmasında önemli bir yere sahipti. Lenin dine bakış açısını "Din Üzerine" isimli kitabında şu şekilde ifade etmiştir;

"Başkaları hesabına çalışmaktan, yerine getirilmeyen isteklerden ve yalnız bırakmışlıktan yılmış halk kitleleri üzerine her yerde büyük ağırlıkla yüklenen ruhsal bask biçimlerinden biri dindir. Doğaya yenik düşen ilk insanların 
tanrllara, şeytanlara, mucizelere ve benzeri şeylere inanmasına yol açışı gibi, sömürülen sınıfların sömürenlere karşı mücadeledeki yetersizliği de kaçınılmaz olarak ölümden sonra daha iyi bir yaşamın varlığına inanmalarına yol açar. Din, bütün yaşamı boyunca çalışan ve yokluk çekenlere, bu dünyada azla yetinmeyi, kusmete boyun eğmeyi, sabırlı olmayı ve öteki dünyada bir cennet итиdunu sürdürmeyi öğretir. Oysa yine din, başkalarının emeğinin sırtından geçinenlere bu dünyada hayırseverlik yapmayı ögreterek, sömürücü varlıklarının ceremesini pek ucuza ödemek kolaylığını gösterir ve cennette de rahat yaşamaları için ehven fiyatlı bilet satmaya bakar. Böylelikle din, halkı uyutmak için afyon niteliğindedir. Din, sermaye kölelerinin insancıl düşlerini, insana daha yaraşan bir yaşam isteklerini içinde boğdukları bir çeşit ruhsal içkidir” (Lenin, 1975, s. 9).

Lenin burada dini bir ruhsal baskı biçimi olarak ifade etmiş ve dini bu dünyada insanlar için cennet umudu vadeden ve insanları uyutan bir afyon olarak tanımlamıştır. Yine aynı eserinde Kiliseye karşı tutumunu da açıkça belirten Lenin, Komünist Partiye de bu anlamda yol göstermektedir;

"Sosyalist proletaryanın partisi açısından din kişisel 'bir konu değildir; Partimiz, işçi sınıfımın kurtuluşu adına bir araya gelmiş sınıf bilinçli, ileri savaşçıların toplandıkları bir yerdir. Böylesi bir birlik i dinsel inanç biçiminde ortaya sürülen sınıf bilinci yoksunluğuna, bilgisizliğe ve geri kafalılığa kayıtsız kalamaz ve kalmamalıdır. Din diye tanımlanan ve halkın üzerine indirilen koyu sisle, sözlerimizi ve yazılarımızı kullanarak tamamen ideolojik silahlarla savaşabilmek için Kilisenin kaldırılmasını istiyoruz. Rus Sosyal Demokrat İşçi Partisini, işçilerin her türlü dinsel uyutmacadan kurtulması adına mücadele etmek için kurduk. Bizim için ideolojik mücadele kişisel bir sorun değil, bütün Partinin, bütün proletaryanın sorunudur” (Lenin, 1975, s. 13).

Lenin'in bu bakış açısı, ateist propaganda için hem kendi dönemindeki takipçilerine hem de gelecekteki takipçilerine dine karşı tutumunu ve yol haritasını göstermektedir. Dinle mücadelenin gerekliliğine vurgu yapan Lenin, ateist propaganda ile tüm dinlere karşı adeta bir savaş açmıştır. 


\section{SOVYETLER BİRLİĞİ'NDE DİN KARŞITI PROPAGANDA}

Sovyetler Birliği’nde din karşıtı propaganda Rusya İç Savaşı sırasında yapılan konferanslar, posterler, broşürler vb. aracılığı ile yapılmaya başlanmıştı (Andrews, 2016, s. 107). Bolşevikler iktidarı ele geçirdikten kısa bir süre sonra ise dine karşı yasaları gündemlerine almaya başladılar. Öncelikle 23 Ocak 1918 yılında çıkarılan bir kararname ile bütün kiliselerin devlet ile olan bağını koparmak amaçlanmıştı. Buna göre ülke genelinde bütün kiliselerin hem devletle hem de eğitim sistemiyle ilişkileri kesildi. Böylece Kilisenin yasal olarak tutunacak bir dalı kalmamış oldu. Diğer taraftan söz konusu mevzuat değişikliği Ortodoks Kilisesine karşı Katolik Kilisesini de güçlendirmiş oldu (Walters, 1986, s. 136-137).

1922 y1lında Lenin'in ölümünden iki sene önce Komünist Parti Genel Sekreteri olarak atanan Stalin de din karşıtı ateist propagandada önemli görevler aldı. Göreve geldikten sonra ilk icraatları arasında OGPU'ya (Ortak Devlet Siyasi Müdürlügü) verilen bir görev olan devlete kimin karşı olduğunu bulmak ve listelemek vardı. Şubat 1924 geldiğinde Stalin'in de görev aldığı OGPU raporunda devlete karşı olanları iç kategoriye ayırarak bildirmişti. Bunlar siyasi partiler, örgütler ve derneklerden oluşmaktaydı. Bu başlıkların altında birçok rahip, haham, diyakoz, Kilisenin önde gelenleri gibi dini aktörler de yer almaktaydı (Childers, 2012, s. 23; Corley, 1996, s. 45). Bununla beraber Sovyetler Birliği yöneticileri sadece Ortodokslara değil, diğer dinlere inananlara da büyük baskılar yapmış, din adamlarını hapsetmiş, Sibirya'daki kamplara göndermiş veya idam etmiştir. Dolayısıyla Sovyetler Birliği'nde sadece belirli bir dine karşı bir propaganda yürütülmemiş, genel olarak bütün dinlere karşı siyasi bir politika yürütülmüştür (Yalçınkaya, 1999, s. 112). Öte yandan Sovyetler Birliği'nde ateizm propagandasında rol alan en önemli kurumlardan birisi de 1925 yılının başlarında kurulan “Tanrısız Militanlar Birliği” isimli örgütlenmedir. "Dine karşı mücadele, sosyalizm için mücadeledir" sloganıyla hareket eden bu örgütlenme, dinlerle olan mücadelede en önde gelen kurumlardan birisidir (Aktaran: Roessler 1990, s. 60).

Bununla beraber Sovyetler Birliği’nin din ile ilgili getirdiği farklı kısıtlamaları ve propaganda çalışmaları vardır. Örneğin çocuklara dini eğitim vermek, dini organizasyon veya gruplar için yardım toplamak, dini grupların özel toplantılar düzenlemesi gibi yasaklamaları mevcuttur (Waltes, 1985, s. 73). Sovyetler Birliği’nin bu adımları, dinlere karşı yeni yetişen nesil ve yetişkin bireyler üzerinde dini propaganda yapmak için uygun zemin hazırlamıştır. 
1930'lu yıllara gelindiğinde Sovyetler Birliği’nde din karşıtı propaganda daha örgütlü bir biçimde yürütülmeye başlandı. Belli başlı örgütler din karşıtı propaganda için çalışmalarını yürütmekteydi. Örneğin bu örgütlerden birisi daha önce bahsedilen “Tanrısız Militanlar Birliği”" isimli örgüttü. 1930'lu yıllarda etkinliğini iyice arttıran bu örgüt, din karşıtı propagandada en ön saflarda yer almaktaydı. Bu örgütün çalışmaları ve yapılan din karşıtı propaganda neticesinde, örneğin Müslümanlara baktığımız zaman o dönemlerde, 30.000 Müslüman din adamının hayatını kaybettiğini görmekteyiz. Bunun yanında İslam karşıtı yapılan diğer propaganda faaliyetleri çerçevesinde yapılan diğer uygulamalara baktığımızda; şeriat mahkemeleri kaldırılmış, İslam dinine mensup olan bireylerin ibadethaneleri, medreseleri ve İslam ile ilgili diğer kurumlar kapatılmış veya laik okullar ve yayınevlerine dönüştürülmüştür. Hatta Müslümanlara ait olan fabrikalar, sosyal örgütler, anaokulları bile kapatılarak din karşıtı propagandanın işleyişi hızlandırılmıştır. Bununla beraber Ramazan ayında oruç tutmak gibi ibadetler de sağliksız olarak kabul edilmiştir (Yemelianova, 2010, s. 21).

İkinci Dünya Savaşı geldiğinde Sovyetler Birliği’nde din karşıtı propaganda faaliyetlerinde bir azalma meydana geldi. Stalin, savaşı kazanmak için her kesimden destek almak zorunda olduğunu biliyordu. Bu nedenle dini gruplar da dahil olmak üzere savaş1 kazanmasına yardımcı olabilecek tüm güçlere ihtiyacı vardı. Stalin, kurulduğundan beri Sovyetler Birliği'nde ateist propagandanın en önemli aktörlerinden birisi olan ve çoğu din karşıtı propagandayı yürüten Tanrısız Militanlar Birliği örgütünün kapatılmasını ve din karşıtı propaganda faaliyetlerinin durdurulması emrini verdi. Böylece 1941 yılına gelindiğinde Tanrısız Militanlar Birliği kapatıldı ve ateist propaganda yapan yayınlar durduruldu. Ayrıca ülke genelinde kiliseler yeniden faaliyete geçti (Corley, 1996, s. 130). Bununla beraber Kızıl Ordu içerisindeki dini kısıtlamalar ve din karşıtı propaganda çalışmaları devam ediyordu (Miner, 2003, s. 79).

1941 y1lından sonra Komünist Parti genel sekreterliği görevine gelen Brezhnev döneminde din karşıtı propagandada önceki dönemlere göre farklılıklar olmuştur. Bu dönemde bir önceki döneme göre din karşıtı propagandanın daha fazla bilimsel yöntemler kullanılarak yapılması gerektiğine karar verilmiştir. Bu bağlamda, bu dönemde din karşıtı propagandada uzman görüşlerden faydalanılmış, dini ritüellerin, kutlamaların, geleneklerin ortadan kaldırılmasının gerekliliği sonucuna varılmıştır. Bu yönde adımlar atılmasına karar verilmiştir (Broxup, 1987, s. 291). 
Dinlere karşı yapılan bütün bu propaganda çalışmalarının ardında Powell'e (1967, s. 5) göre Komünist Partinin dört hedefi vardır:

1- Siyasi sistemleri ve yapıları dini ideolojilerden ayırmak.

2- Dini çevreler tarafından yürütülen sosyo-ekonomik işlevlerin siyasi otorite tarafından yürütülmesini sağlamak.

3- Politik kültürü, akı1cı ve pragmatik bakış açısıyla yeniden yapılandırmak.

4- Dini inanç ve pratikleri tamamen ortadan kaldırarak ateist bir toplum oluşturmak.

$\mathrm{Bu}$ hedefler çerçevesinde Sovyetler Birliği'nde din karşıtı propaganda için kullanılabilecek bütün araçlardan faydalanılmıştır. Söz konusu propaganda faaliyetleri ise medya, eğitim ve yüz yüze olmak üzere farklı alanlarda ve tekniklerde kendisini göstermiştir.

\subsection{Medya}

Medya her zaman propagandada önemli bir yere sahiptir. Zira medya içerisinde yer alan gazete, televizyon, sinema vb. araçlar aynı zamanda propaganda amaçlı da kullanılmaktadır. Sovyetler Birliği'nde de bu araçlar Komünist Partinin yürüttüğü bütün propaganda çalışmalarında etkin bir biçimde kullanılmıştır. Bununla birlikte Sovyetler Birliği’nde din karşıtı propagandada en fazla kullanılan medya aracı gazete olmuştur. Dinleri adeta bir canavar gibi gösteren gazeteler hem ateistlere hem de inançlılara yönelik propaganda faaliyeti yürütmüştür (Powell, 1967, s. 168-169). Lenin de ateist propaganda yapmak için gazetenin önemli olduğunu vurgulamıştır. Ateist militanlarının bir basın organına sahip olmak zorunda olduğunu söyleyen Lenin'in bu konuyla alakalı aşağıdaki sözleri gazetenin din karşıtı propagandadaki önemini açıkça göstermektedir;

"Bir gazetenin militan ateist bir organ olması gerekir. Bu işle uğraşan dairelerimiz, ya da en azından devlet kuruluşlarımız var. Ne var ki, işler son derece ağır ve doyurucu olmaktan uzak biçimde yürütülmekte, (Sovyet bile olsa) Ruslara özgü bürokratik çarkın genel koşullarından zarar görmektedir. $\mathrm{Bu}$ nedenle, bu devlet kuruluşlarının çalışması yanı sıra, bu çalışmaları canlandırmak için, militan maddecilik propagandası yapacak bir gazetenin ateist propaganda yapmasi ve usanmaksızın ateizm mücadelesi vermesi de gereklidir. Bu konuda bütün dillerde yayınlanmış yazılar dikkatle izlenmeli ve 
bu alanda değerli görülen her şey Rusçaya çevrilmeli, en azından tanıtma yazılarlyla okurlara aktarlmalıdır” (Lenin, 1975, s. 99-100).

Ateizm propagandasının yapıldığı ilk gazetelerden birisi olan "The Godless" (Bezbozhnik) isimli gazete Aralık 1922 yılında Moskova'da yayınlanmaya başlamıştır. Gazete, zamanla bütün Sovyetler Birliği'ne dağıtılır hale gelmiştir (Childers, 2012, s. 25). Bezbozhnik din karşıtı propagandada en önemli gazete olarak öne çıkmaktadır. Aynı zamanda daha önce bahsedilen Tanrısız Militanlar Birliği yapılanmasının da bir yayın organı olan bu gazete dışında da Sovyetler Birliği'nde sayısız din karşıtı propagandada görev alan gazete ve dergi mevcuttu (Peris, 1998, s. 74). Bundan başka Sovyetler Birliği ilk dönemlerinde din karşıtı propaganda yapmak için kurulan dergi ve gazetelerden Antireligioznik (Anti-din), Voinstvuyushchiy Atheism (Militan Ateizmi), ve Derevensky Bezbozhnik (Tanrısız Köy) isimli yayınlar da mevcuttur (Conquest, 1968, s. 18). Bilindiği gibi Sovyetler Birliği tüm dinlere karşı bir propaganda yürütmekteydi. Bunun en somut örneklerinden birisi 1929 y1lında Bezbozhnik isimli derginin kapağında Tanrı olmadan 5 yıl mesajı ile Yahudilik, İslam ve Hristiyanlık dinleri sembolize edilerek, bu dinlerin Sovyetler Birliği 5 yıllık kalkınma planı tarafından ezildiğinin resmedilmesidir (Resim 1). Agresif bir biçimde yapılan bu propaganda örneği, Sovyetler Birliği’ndeki din karşıtlığının anlaşılması için dikkat çekici örneklerden birisi olarak ele alınabilir.

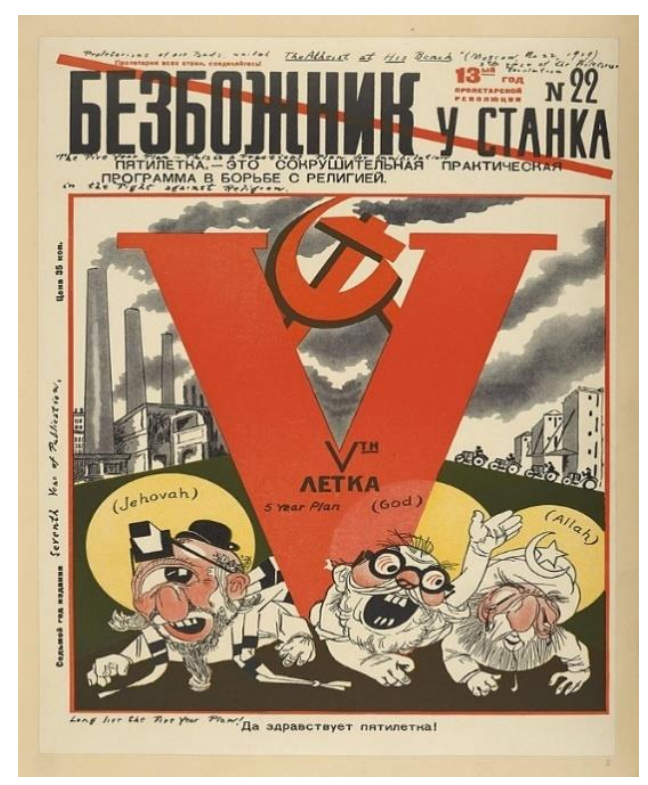

Resim 1.: "Bezbozhnik dergisi kapağı 1929"

Kaynak: (wikipeida.org, 2020) 
Diğer taraftan 1920-1941 yılları arasında din karşıtı propaganda faaliyeti yürüten gazeteler incelendiğinde Sovyetler Birliği'nde ateist propagandada gazetenin yeri ve önemi daha iyi anlaşılmaktadır. Yukarıda da bahsedilen din karşıtı propagandada en önemli yayınlardan olan Bezbozhnik'in (Tanrisız) gazete versiyonu 1925 yılında 210,000 tiraja ulaşırken 1930 yılında 500,000 rakamına ulaşmıştır. Genelde 4-16 sayfa arası çıkan Bezbozhnik (Tanrısız) gazetesi haftalık olarak çıkmaktaydı. Dergi olarak basılan Bezbozhnik ise iki haftada bir ve ayda bir olarak zamanla 35,000 adet basımdan 65,000 adete çıkmıştır. Ukraynaca çıkan bir başka ateist propaganda gazetesi olan Voiovnicheii vezvirnik'in 1931 yılında 200,000 adet basıldığı tahmin edilmektedir. Bunun yanında diğer etnik gruplara yönelik olarak çıkan ve Rusça olmayan diğer ateist propaganda dergileri ise şunlardır; 1922-1933 yılları arasında Bakü'de Azeri Türkçesinde yayınlanmış olan Allahsyz dergisi, 1928-1934 yılları arasında Erivan'da Ermenice yayınlanmış olan Anastvast dergisi (Resim-2), 1923-1924 y1lları arasında Kiev'de Ukraynaca yayınlanmış olan Bezvirnik dergisi, 1931-1935 yılları arasında Moskova'da Yiddish (Almanca-İbranice) dilinde Yahudilere yönelik olarak çıkarılan Der Apikories dergisi, 1928-1933 y1lları arasında Taşkent'te Özbekçe yayınlanan Khudosilzar dergisi, 1928-1935 yılları arasında Ufa'da Başkurt dilinde yayınlanan Allakhyz dergisi, 1925-1935 yılları arasında Kharkov'da Ukraynaca yayınlanan Bezvirnik dergisi, 1929-1935 yılları arasında Moskova'da Polonyaca yayınlanan Bezboznik wojuiacy dergisi, 1937-1941 y1lları arasında Tiflis’te Gürcüce yayınlanan Mebdrzoli Ateisti dergisi, 1925-1937 yılları arasında Moskova'da Tatarca yayınlanan Sugyshan Allasyz dergisi, 1928-1934 y1lları arasında Verkhne Udinsk'de (RusyaBuryat Özerk Cumhuriyeti Başkenti) Buryatça yayınlanan Erdem ba Shazhan dergisi, 19261934 yılları arasında Kharkov'da Almanca yayınlanan Neuland dergisi ve 1930-1931 yıllarında Tiflis’te Gürcüce yayınlanan Religiis Tsinaalmdeg dergisi (Peris, 1998, s. 74). Sovyetler Birliği’nde Tanrısız Militanlar Birliği örgütlenmesinin çabasıyla, birçok farklı dille yayınlanan bu dergi ve gazeteler ile sadece Ruslar üzerinde değil, diğer etnik gruplar arasında da din karşıtı propaganda yapmak amaçlanmıştır. Diğer taraftan 1953 yılında Nikita Kruşçev'in göreve gelmesiyle Sovyetler Birliği’nin din karşıtı propaganda politikalarında yeniliklere gidilmeye çalışılmıştır. Bilimsel yöntemlerin kullanılması amacıyla 1957 yılında "Bilimsel Ateist Propagandada Eksiklikler ve Kapsamlı Önlemler” isimli bir kararname çıkarılmıştır. Söz konusu kararnamede din karşıtı propaganda çalışmalarının nasıl yapılacağı açıklanmıştır. Kararnamede yer alan bu çalışmalardan birisi de Nauka i Religiya (Bilim ve Din) isimli bilimsel bir derginin yakın gelecekte çıkarılması için hazırlıklara başlanmasıdır (Childers, 2012, s. 59). 


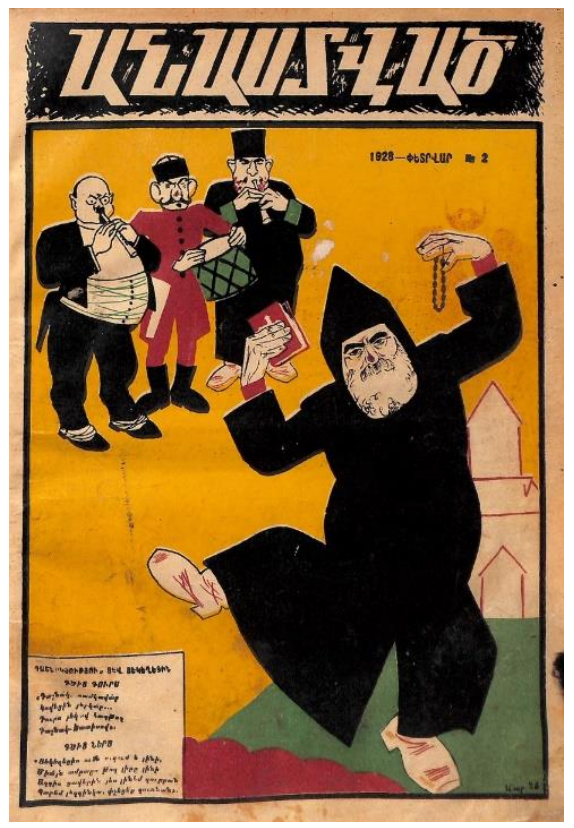

Resim-2. “1928 yılında Erivan’da Ermenice yayınlanmış Anastvast dergisi kapağı”

Kaynak: (wikipeida.org, 2020)

Propagandada öne çıkan bir diğer medya aracı ise televizyondur. Sovyetler Birliği propaganda makinesi gerek din karşıtı propagandada gerekse de diğer propaganda çalışmalarında televizyonu çok fazla tercih etmemiştir. Bunun en önemli nedeni o dönemlerde televizyonun hem yeni bir araç olması hem de toplumda yaygın olmamasıdır. Televizyon ancak 1953 yılında Stalin'in ölümünden sonra Sovyetler Birliği’nde gerçek anlamda yayılmaya başlamıştır. Ancak yine de lüks tüketim ürünü olduğu için yeterince yaygınlaşmamıştır. Bu nedenlerle yazılı ve basılı araçlarla yapılan propaganda uygulamaları ile yüz yüze propaganda uygulamaları daha fazla öne çıkmıştır (Powell, 1967, s. 206; Dizard, 1963, s. 39).

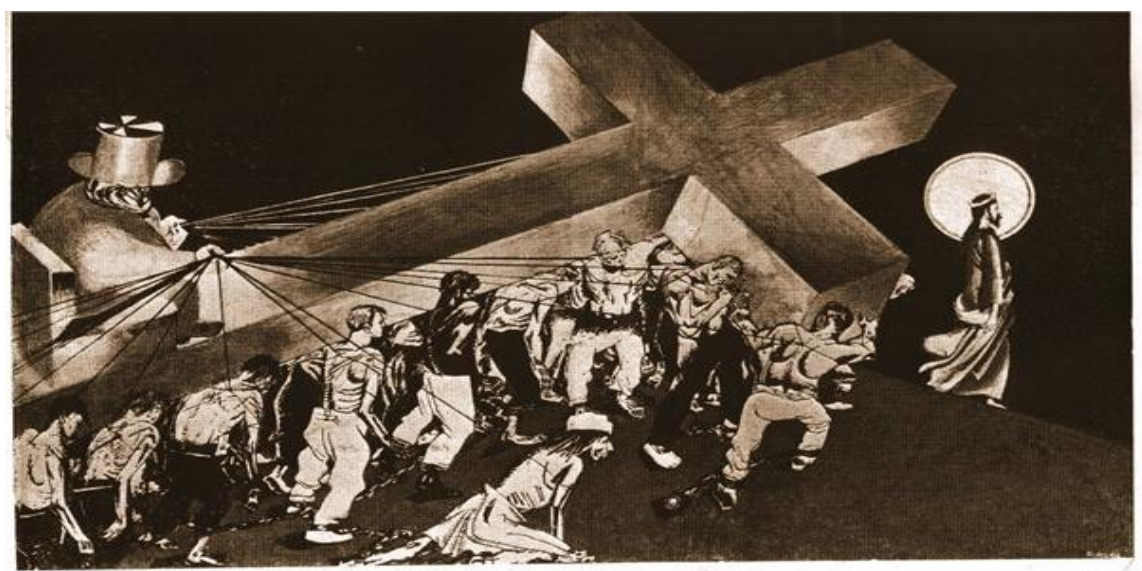


Resim 3. 1927- Devrimin 10. Yılı dolaysıyla Tanrısız Militanlar Birliği tarafından hazırlanan bir karikatür

Kaynak: (avtopilot-center, 2020)

Sovyetler Birliği propaganda makinası propaganda arac1 olarak sinemadan da faydalanmıştır. Lenin'in “en önemli sanat” dediği sinema, Sovyetler Birliği’nde propaganda amacıyla kullanılan en önemli araçlardan birsi olarak karşımıza çıkmaktadır. Zira sinema okuma yazma bilmeyen bireylerle iletişim kurmak için o dönemde bulunmaz bir firsat sunmaktaydı. Sovyetler Birliği’nin oluşturmak istediği ateist toplum hedefi için aynı zamanda hızlı da bir propaganda aracıydı. Sinematik bir propaganda makinasının kurulması aynı zamanda eğitim projesinin de önemli bir parçasıydı (Widdis, 2003, s. 13). Sinema, Bolşevikler nezdinde çok önemli bir propaganda aracıydı ve Bolşevikler arasında önemli bir silah olarak görülüyordu. Bolşevik siyasetçi ve teorisyen Troçki Çarlık Rusya’sının kitleler üzerinde etki sağlamak için Kilise ve dinden faydalandığını, sosyalist devletin ise kitleleri aydınlatmak için sinemanın kullanılması gerektiğini vurgulamıştır. Dönemin ünlü sinemacısı ve yönetmeni Dziga Vertov da Troçki ile benzer düşüncelere sahiptir. Fakat Vertov sinemanın drama yerine daha çok eğitim aracı olarak kullanılması gerektiğini vurgulamıştır (Taylor, 1992, s. 55).

\subsection{Yüz Yüze Propaganda}

Daha önce de belirtildiği gibi Sovyetler Birliği’nde propaganda çalışmalarının temelinde Lenin'in önemli bir yeri vardır. Bundan ötürü Lenin, Sovyetler Birliği propaganda politikasında bir yol gösterici konumundadır. Hatta günümüzde siyasal iletişim literatüründe Lenin'in kullandığı propaganda teknik ve yöntemleri, Lenin türü propaganda olarak yerini almış bulunmaktadır. Lenin türü propagandanın temeline bakıldığında ise karşımıza iki kavram çıkmaktadır. Bunlar siyasal açımlama ve paroladır. Siyasal açımlama, kanıtlar kullanılarak yapılan propagandadır. Örneğin iktidarların gerçek yüzlerini topluma kanıtlar sunarak göstermek amaçlanır. Parola ise propagandanın özünü kısa ve basit bir biçimde hedef kitleye sunar. Parola, propagandanın savaşçı yanıdır. Dolayısıyla kitlelerin anlayabileceği düzeyde olması gerekir. Parolanın hedef kitle üzerinde yayılması ise iki yolla yapılır; propagandacılar ve kışkırtıcılar. Propagandacılar parolayı tek bir kişi ya da küçük bir gruba yayarken, kışkırtıcılar ise aynı parolayı daha büyük kitlelere yaymak için çalışırlar (Domenach, 1995, s. 31-33). Din karşıtı propaganda çalışmalarında da bu durum geçerlidir. Yüz yüze yapılan din karşıtı propaganda çalışmalarında dinsizlik, ateizm gibi olgular, propagandacı ve kışkırtıcılar aracılığı ile hedef kitleye empoze edilmeye çalışılmıştır. Din karşıtı olan bu kışkırtıcılar diğer 
araçlarla beraber yüz yüze olarak da insanlarla iletişime geçmeye çabalamış ve tartışmalara girmişlerdir. $\mathrm{Bu}$ teknik ile kitle iletişim araçları ile ulaşılamayan bireylere ulaşma imkânı bulunmuştur. Öte yandan Sovyet propaganda uzmanları yüz yüze propagandada hedef kitle ile etkili bir iletişim kurulabilmesi için dikkat edilmesi gereken önemli noktalar olduğunu kabul ederler. Örneğin yüz yüze iletişimde vurgulamanın propaganda için önemli bir kural olduğu propaganda uzmanlarına öğretilmiştir (Powell, 1967, s. 214). Bununla birlikte dini propaganda yüz yüze iletişim yoluyla yapılırken hedef kitle ile temas kurmak, donukluktan ve tekrardan kaçınmak, karmaşık ifadelerden ziyade dinleyicinin anlayabileceği kelimeler kullanmak, çarpıcı örnekleri propagandanın içine serpiştirmek, alaycı ve küçük düşürücü ifadeler kullanmak, propagandada mizaha yer vermek gibi noktalar yüz yüze propaganda yapacak olan propagandacı ve kışkırtıcılara öğretilmiştir (Aktaran: Powell, 1967, s. 215). Din karşıtı propagandada hedef kitlenin birlik oluşturmasını önlemek için de adımlar atılmıştır. Örneğin özellikle çoğunluğu Ortodoks olan Sovyetler Birliği'nde cemaatlerin bir araya gelmesini engellemek için tatil günleri üzerinde de değişiklikler yapılmıştır. Din temelli olarak değiştirilen tatil günleri pazar gününden alınarak cumartesi gününe kaydırılmıştır. Böylece dini yapıların etkisinin azaltılması amaçlanmıştır. Bununla da yetinmeyen komünistler dinlerin kutsal günlerini kısıtlayabildikleri kadar kısıtlamıştır. Bunların yerine ise 1 Mayıs Uluslararası Emek Günü veya 7 Kasım Bolşevik Devrimi’nin yıldönümü gibi özel günler getirerek kitleler üzerinde propaganda çalışmaları yapmışlardır. Hatta yeni yıla girmeden önce Hristiyanlar tarafından kutlanan Noel bayramının üzerinde bile değişikliğe gidilmiştir. Noel baba figürü yerine "Buz (Frost) Amca" figürü getirilerek bu noktada dahi din karşıtlığı yapılmıştır (Lamont, 1936, s. 11-12).

Sovyetler Birliğii'nde Komünist Parti için din karşıtı propagandayı etkili kılmak için dinlerin ibadethaneleri üzerinde baskı kurmak istenmiştir. Kilise ve camiler başta olmak üzere ülke genelinde ibadethaneler kapatılarak ya da sayıları azaltılarak ateist propagandanın daha etkili olması amaçlanmıştır. Örneğin 1917 yılına kadar Tataristan bölgesinde mevcut cami sayısı 2223 iken 1930'lara gelindiğinde bu say1 980'e kadar düşmüştür. Kabardey-Balkariya ve Adige bölgesinde ise tek bir cami kalmamıştır (Yemelianova, 2010, s. 21).

\subsection{Eğitim-Öğretim}

Sovyetler Birliği’nde din karşıtı propaganda yapılan alanların başında eğitim ve öğretim gelmektedir. Eğitim sisteminde görev alan ateist öğretmenler din karşıtı propagandada önemli 
görevler üstlenmekteydi. Lenin tarafından ortaya konulan ateist öğreti, eğitim öğretim mekanlarında ve iş yerlerinde sorgulanmadan uygulanıyordu (Broxup, 1987, s. 290-291). Bilindiği üzere Marksizm sadece politik ya da ekonomik bir doktrin değildir. Aynı zamanda tarih, sanat, felsefe gibi disiplinler üzerinde keskin bir bakış açısına sahip bir dünya görüşüdür. Bu nedenle Marksizm'in din karşıtlığı ve ateist propagandası eğitim öğretimde de kendini göstermiştir (Lamont, 1936, s. 13). Lenin özellikle komünizmin yayılmasında ve aktarılmasında eğitim-öğretime ayrı bir önem veriyordu. Lenin'in eğitim-öğretimle ilgili aşağıdaki sözleri Sovyetler Birliği’nde eğitim ve öğretimin yerini anlamak için önemlidir;

“Önemli nokta şudur ki, eski, kapitalist toplumun değişmesiyle, komünist toplumu kuracak yeni kuşakların yetiştirilmesi ve eğitilmesi eski yöntemlere göre yürütülemez. Gençliğin yetiştirilmesi, eğitimi ve ögrenimi, eski toplumdan bize kalan malzemeden hareketle geliştirilmelidir. Ancak bilgi, örgütler ve kuruluşlar bütünlüğüne dayanarak, ancak eski toplumdan bize devrolunan insan gücü ve aracı stokundan yararlanarak komünizmi kurabiliriz. Ancak gençliğin öğrenimini, örgütlenmesini ve eğitimini radikal olarak yeniden biçimlendirmekle, genç kuşağın çabalarının eskisine benzemeyen bir toplum yaratmak, yani komünist toplum kurmak sonucuna ulaşmasını güven altına alabiliriz. Isste bu nedenle, gençliğe ne ögreteceğimiz ve gençliğin, komünist gençlik tanımını gerçekten hak etmek için öğrettiklerinizi nasıl öğreneceği, bizim başladı̆̆ımızı tamamlamak için nasıl ĕgitileceği sorunlarını ayrıntılı olarak ele almallyız" (Lenin, 1975, s. 74-75).

İkinci Dünya Savaşı sonrasının aksine Sovyetler Birliği'nde 1920'li yıllarda yapılan din karşıtı propaganda daha merkezileşmiş bir biçimde yürütülmekteydi. Halk arasında bilimsel ve Marksist dünya görüşünü hâkim kılmak için çabalayan Sovyetler Birliği bunun için bilim adamları, editörler, entelektüeller ve propagandacılar yetiştirdi. Bunun yanında din karşıtı propaganda için eğitim faaliyetlerini önemseyen Sovyetler Birliği’nde yayınevleri, gönüllü dernekler, bilimsel kuruluşlar söz konusu din karşıtı kampanyaya yardım ediyorlardı. İleride Stalin döneminde de din karşıtı propagandada bilimsel eğitimin önemi vurgulanacaktı (Andrews, 2016, s. 107). Ancak daha öncesine baktığımızda özellikle Lenin döneminde eğitim öğretim aracılığı ile yapılan ateist propaganda daha fazla öne çıkmaktaydı. Zira Lenin ateist propagandanın eğitim yoluyla yapılmasına çok önem veriyordu. Bu nedenle özellikle 
köylülerin dini değerlerini yok etmek için eğitim öğretimde de dine bir cephe açmıştı. Akla gelebilecek her türlü araçla dinlere saldıran Lenin, yüksek öğretim kurumlarında dahi din karşıtı bölümler açmıştır (Lamont, 1936, s. 11).

10 Temmuz 1918 yılında kabul edilen anayasada din ile ilgili maddeler yer alıyordu. $\mathrm{Bu}$ maddelerden eğitim konusunda din adamlarına ve ailelerine bazı kısıtlamalar getirilmesi ile ilgili maddeler de yer almaktaydı. Buna göre din adamları çocuklarını ilkokul seviyesinden sonra okula gönderemiyorlardı. Dini eğitim ise daha önce 23 Ocak 1918 yılında çıkarılan yasayla yasaklanmıştı. Sadece özel okullarda dini eğitime izin veriliyordu. Ancak 13 Haziran 1921 yılında çıkarılan bir kararname ile on sekiz yaş altındaki bireyler için bu da yasaklandı. Stalin dönemine gelindiğinde ise eğitimle ilgili yapılan bu kısıtlamalardan taviz verildiği görülmektedir. Stalin döneminde din adamlarının çocuklarına tekrardan yüksek öğrenim görme hakkı getirilmekle beraber 1930'ların başlarında ateist yayınlarda da azalma görülmüştür (Conquest, 1968, s. 14-24). Devletten hariç olarak Tanrısız Militanlar Birliği de 1925 yılından itibaren din karşı1tı propagandanın eğitim üzerinden yapılması gerektiğini savunmuştur. Ancak birlik daha sonraki yıllarda dinle mücadelede daha agresif bir tutum izlemiştir (Smith, 2016, s. 7).

Ateist propagandada önemli bir başka yöntem ise seminerler yoluyla yapılan propagandayd1. 1920’lerde din karşı1tı seminer sayıları gözle görülür bir artış göstermiştir. Örneğin 1925 yılında din karşı1tı seminer sayısı dokuz iken 1926 yılında kırk dokuz, 1927 yılında altmış sekiz, 1928 yılında seksen dokuz olarak kayıtlara geçmiştir. Bunlardan başka ise 1927 yılında on beş adet referans merkezi kurulmuş, 1928 yılında din araştırmaları yapmak için Komünist Parti içerisindeki kızıl profesörler tarafından “Din Araştırma Makamı” kurulmuştur (Conquest, 1968, s. 18-19).

Din karşıtı propaganda için kitaplardan da faydalanılmıştır. 1930'larda popüler klasik bilimsel kitapların basımı ve yayımı için çaba sarf edilmiştir (Andrews, 2016, s. 115). Ayrıca ateizm konusundaki propagandanın tamamen bilimsel ve materyalist dünya görüşüne dayandırılması gerekiyordu. Bu nedenle din karşıtlığını açıklarken konunun tarihi ve ekonomik kökenlerine inmek gerekiyordu. Bu bağlamda din karşıtı propaganda için gerekli bilimsel yayımların yapılması gerekiyordu. Bu nedenle Lenin, 18. yüzyıl Fransız Aydınlanma dönemi düşünür ve ateistlerinin yazılarının çevrilmesini ve yayımlanmasını bir gereklilik olarak görmüştür (Lenin, 1975, s. 13-14). 


\section{SONUÇ}

Propaganda birçok türü ve tekniği bulunan, kitleleri etkisi altına alan önemli bir ikna silahıdır. Özellikle savaş dönemlerinde ve siyasi kampanyalarda kendisini gösteren propaganda, tarihte birçok devlet ve siyasi tarafından farklı amaçlarla kullanılmıştır. Bunun en önemli örneklerinden birisi de hiç şüphesiz Sovyetler Birliği'nde dinlere karşı yapılan ateist propagandadir.

Bilindiği gibi Sovyetler Birliği, Ekim Devrimi’nin gerçekleştirildiği ve Bolşeviklerin iktidara geldiği 1917 yılından, dağıldığı yıl olan 1991 yılına kadar sosyalist dünya görüşüne sahip olan bir devlet olmuştur. Dolayısıyla bu süre boyunca da gerek zorlamalarla gerekse de ikna yöntemleri ile ateist bir toplum oluşturmayı hedeflemiştir. Sovyetler Birliği’nin özellikle 1917-1960 arası dönemi, ateist propagandanın en şiddetli yapıldığı dönem olarak ele alınabilir. Zira bu dönemde ateist propaganda devletin bir politikası olarak eğitim-öğretimden, kitle iletişim araçlarına kadar her alanda ve araçta açıkça kendisini göstermiştir.

Sovyetler Birliği’nde din karşıtı propaganda devletin kurulduğu ilk günlerden itibaren yapılmaya başlanmıştır. Çünkü Lenin herhangi bir dine inanan her bir vatandaşın dinler tarafından yanıltılmış olduğunu düşünüyordu (Childers, 2012, s. 99). Sovyetler Birliği’nde Lenin'den sonra gelen liderler de benzer düşüncelerle hareket ederek bütün dinlere karşı örgütlü ve devlet destekli bir propaganda faaliyeti yürütmüştür. Ateist propaganda için faydalanılabilecek bütün imkanlardan faydalanılan Sovyetler Birliği'nde propaganda çalışmaları özellikle medya, yüz yüze ve eğitim-öğretim yoluyla yapılmıştır.

1917-1960 arasında yapılan ateist propaganda, İkinci Dünya Savaşı ve sonrası dönemde etkisini kaybetse de önceki dönemde acımasız ve agresif bir biçimde yapılmıştır. Bu noktada ise yapılan bütün bu propaganda çalışmaları acaba gerçekten hedefine ulaşmış mıdır? sorusu akıllara gelmektedir. 1960 yılına gelindiğinde Sovyetler Birliği’nde ateist propagandanın etkili olmadığı, aksine ateist propagandanın dindarlığı daha da körüklediğine ilişkin verilere ulaşılmıştır. Örneğin Rusya Kostroma Bölgesi Yürütme Komitesi tarafından 1961 Mayıs ayında bütün ilçelere ve başkanlara gönderilen bir raporda Kostroma bölgesindeki bütün dini örgütlerin faaliyetleri ile ilgili önemli bilgilere ulaşılmıştır. Buna göre yapılan bütün ateist propaganda çalışmalarına rağmen bölge insanının dindarlığının azalmadığına, aksine daha da arttığına vurgu yapılmıştır. Raporda bunun kanıtı olarak da yapılan araştırmalar neticesinde; 
1959 yılına kıyasla 1960 yılında bölgedeki ayinlere katılım oranının arttığı, 1959 yılında yeni doğanların \%35'inin vaftiz edilirken, 1960 yılında ise \%38'inin vaftiz edildiği belirtiliyordu. Ayrıca 1959 yılında bölgede hayatını kaybeden insanların \%27'sinin dini ayinlerle gömülürken, 1960 yılında bu oranın \%35,5'e yükseldiği vurgulanmıştır (Corley, 1996, s. 221-222). Ancak bu noktada Sovyetler Birliği'nde yapılan din karşıtı propagandanın hiçbir etkisi olmadığını söylemek de yanlış olur. Zira 1917 yılından itibaren yapılan ateist propaganda sonucunda 1930'ların sonuna doğru, İkinci Dünya Savaşı başlamadan önce Sovyetler Birliği’nde din karşıtı hareket önemli ilerlemeler de kaydetmiştir. Örneğin İkinci Dünya Savaşı'ndan önce Moskova'daki kiliselerin \%80'i kapatıldı. Önemli sanayi merkezlerinde hemen hemen hiç dini bir ibadethane kalmadı. Bir dönem Tanrısız Militanlar Birliği başkanı da olan Emelian Yaroslavsky, yapılan ateist propaganda neticesinde, 1930'lu yılların sonuna doğru yaklaşı 170 milyon nüfusa sahip olan Sovyetler Birliği'nde 40 milyon ateist olduğunu iddia ediyordu (Lamont, 1936, s. 18). Bu sayı genel nüfusun neredeyse \%25'ine karşıllı gelmekte, bir başka ifadeyle 1930'ların sonuna doğru Sovyetler Birliği'nde her dört kişiden birinin ateist olduğunu göstermektedir. Bu durumun ortaya çıkmasında hiç şüphesiz Sovyet din karşıtı propaganda makinesinin önemli bir etkisi olduğu açıktır.

\section{EXTENDED ABSTRACT}

Propaganda, whose origins are as old as human history, has been used for many years to persuade people. There are many examples of propaganda used by different actors in different periods of history. But especially 20. With the century, studies on propaganda stand out more. It is an undeniable fact that developments in the field of mass communication in particular have an important role in the formation of this situation. Another important example of propaganda works, especially in the First World War and Second World War period, is the propaganda works made during the Soviet Union.

In November 1917, a new era began with the overthrow of the Tsarist regime in Russia. With the revolution, the Soviet Union was established under the short name of the Union of Soviet Socialist Republics (USSR), one of the most important states with a socialist world view. Founded under the leadership of Lenin, this state influenced many people ideologically and socially from its inception until the year of its collapse, 1991. Since the first days of the revolution, the Soviet Union has started to work for the acceptance of the new regime in society. In the Soviet Union, which was aiming to design society with a socialist world view, it used all 
the tools it could use to achieve this goal. From cinema to theatre, media to literature, all tools have been used to place the socialist worldview in society. As it is known, it has a structure that is against all religions based on the socialist world view. The views of Karl Marx and Friedrich Engels, considered the founders and most important figures of socialism, on religion undoubtedly influenced Vladimir Lenin, the socialist revolutionary and founder of the Soviet Union. Therefore, policies against religions began to be developed in the Soviet Union after the revolution. Not only Lenin, but the later rulers of the Soviet Union continued These antireligious policies. Atheist propaganda was made a policy of the state and carried out systematically effectively throughout the country. However, in order to understand the antireligious propaganda in the Soviet Union, one must first look at the period before the revolution. Because some policies implemented by the Tsarist regime before the October Revolution can be said to facilitate the work of anti-religious propaganda made after the revolution. This is because of the Tsarist regime's relationship with the Orthodox Christians and church, which is the most active religion in Russia. Before the revolution there was a relationship of mutual interest between the Tsarist regime and the Orthodox Church. Those who opposed the regime were identified and punished through the church. In addition, the church was propagandizing about the legitimacy and continuity of the Tsarist regime. In return, the leaders and clergy of the Orthodox Church had considerable wealth financially. Therefore, this situation was preparing the ground for the formation of negative thoughts in the eyes of the public against both the Tsarik regime and the church. However, when the literature is examined, it is possible to consider the anti-religious propaganda carried out in the Soviet Union in three main headings. These titles stand out as atheist propaganda works made through the media, atheist propaganda works made through education and atheist propaganda works made face to face.

Media is one of the most important tools used as a propaganda tool. It was also used effectively in anti-religious propaganda in the Soviet Union. Especially newspapers and magazines have taken on important tasks in this sense. Atheist propaganda magazines and newspapers published in different languages were tried to be sent all over the country. On the other hand, television could not be used as an effective tool in atheist propaganda because it was not fully developed and spread in society between 1917-1960. Instead, radio and cinema were used more effectively. It has resulted in the effective use of radio and cinema by Socialists, especially because of its advantage in reaching illiterate individuals. Another method used by 
socialists in atheist propaganda is face-to-face propaganda. Individuals were asked to be reached through conferences or instigators. In this way, it is aimed to reach the target audience that cannot be reached by mass media. One of the areas where atheist propaganda has an important place in anti-religious propaganda is education and training. The leaders who came after him, especially Lenin, gave great importance to education and training for the spread of atheism. For this, the books of Karl Marx and Friedrich Engels were translated and printed. Children of clergy were prevented from attending higher schools and departments related to atheism were opened in higher education.

In this study, which used the literature survey method, a theoretical evaluation of the antireligious propaganda works carried out in the Soviet Union between 1917-1960 was made. The Evaluation concluded that in the period between 1917 and the Second World War, the Soviet Union carried out an aggressive propaganda campaign against all religions, not just Christianity. It was only before and during the Second World War that a softening was observed in these studies. This is because Stalin, the leader of the Soviet Union at the time, needed the support of all sectors for the war. In the later period, anti-religious propaganda was tried to be carried out on a scientific basis.

\section{KAYNAKÇA}

Andrews, J. T. (2016). Inculcating materialist minds: Scientific propaganda and anti-religion in the USSR during the Cold War. P. Betts, ve S. A. Smith (Ed.), Science, Religion and Communism in Cold War Europe (s. 105-125) içinde. London: Palgrave Macmillan.

Avtopilot-center. (2020, Temmuz 15). Devrimin 10. yılı dolayısıyla Tanrısız Militanlar Birliği tarafından hazırlanan bir karikatür. Erişim adresi: avtopilot-center.ru: https://avtopilotcenter.ru/bez-boga-v-golove-kak-zhurnal-bezbozhnik-u-stanka-borolsya-s.html Bernays, E. (1928). Propaganda. California: Liveright.

Broxup, M. (1987). Islam in central Asia since Gorbachev. Assian Affairs, 18(3), 283-293.

Bezbozhnik dergisi kapağı. (2020, 16 Temmuz). Vikipedi içinde. Erişim adresi:

https://en.wikipedia.org/wiki/League_of_Militant_Atheists\#/media/File:\%D4\%B1\%D 5\%86\%D4\%B1\%D5\%8D\%D5\%8F\%D4\%BF\%D4\%B1\%D4\%BE.jpg 
Childers, B. (2012). The plurality of Soviet religious "policy” (Yüksek Lisans tezi, Florida State Üniversitesi). Erişim adresi: https://search.proquest.com/docview/1034595413?accountid=15875

Conquest, R. (1968). Religion in the USSR. New York: Praeger.

Corley, F. (1996). Religion in the Soviet Union. New York: New York Universty Press.

Dizard, W. P. (1963). Television in the USSR. Problem of Comunism, 12(6), 38-45.

Domenach, J. M. (1995). Politika ve propaganda. (T. Yücel, Çev.) İstanbul: Varlık Yayınları.

Hart, C. (1998). Doing a literature review: Releasing the social science research imagination. London: Sage Publications.

Kılıç, R. (2006). Misyonerlik ve Türkiye’ye yönelik misyoner faaliyetleri. Türklük Bilimi Araştırmaları, 19, 327-342.

Lamont, C. (1936). Soviet Rusia and religion. New York: International Pamphltes.

Lasswell , H. D. ve Blumenstock , D. (1939). World revolutionary propaganda. New York: Alfred Knopf.

Lenin, V. I. (1975). Din üzerine. (S. C1lızoğlu, Çev.) İstanbul: Ser Yayınevi.

Lenone, M. (2017). Slience propaganda: A semiotic inquiry into the ideologies of taciturnity. Signs and Society, 5(1), 154-182.

Miner, S. M. (2003). Stalin's holy war religion, nationalism, and alliance politics, 1974-1945. London: The Universty of North Carolina Press.

Peris, D. (1998). Storming the heavens: The Soviet league of the militant godless. Ithaca: Cornell Universty Press.

Powell, D. E. (1967). Anti-religious propaganda in the Soviet Union: 1959-1963

(Yayımlanmamıș Doktora tezi, Yale Üniversitesi). Erișim adresi: https://search.proquest.com/docview/287949464?accountid=15875

Qualter, T. H. (1980). Propaganda teorisi ve propagandanın gelişimi. Ankara Üniversitesi Siyasal Bilgiler Fakültesi Dergisi, 35(1), 255-307. 
Roessler, M. F. (1990). Atheism in the Soviet Union: Policy and practice, 1917-1941 (Yüksek Lisans tezi, Kalifornia Üniversitesi). Erişim adresi: https://search.proquest.com/docview/303939547?accountid=15875

Smith, S. A. (2016). Introduction. P. Betts, ve S. A. Smith (Ed.), Science, religion and communism in Cold War (s. 1-31) içinde. London: Palgrave Macmillan.

Taylor, R. (1992). Ideology and popular culture in Soviet cinema: The kiss of Mary Pickford. A. Lawton (Ed.), The red screen politics, socetiy, art in the Soviet cinema (s. 43-66) içinde. New York: Routledge.

Walters, P. (1985). Soviet policy on religion. Soviet Jewish Afairs, 15(1), 72-78.

Walters, P. (1986). The Russian Orthodox Church and the Soviet State. The American Academy of Political and Social Science, 483, 135-145.

Widdis, E. (2003). Visions of a new land: Soviet film from the revolution to the Second World War. New Haven: Yale Universty Press.

Yalçınkaya, A. (1999). Yetmiş yıllık kriz. İstanbul: Beta.

Yemelianova, G. M. (2010). Radical Islam in the former Soviet Union. London: Routledge. 